Article

\title{
Sea Breeze Front and Outdoor Thermal Comfort during Summer in Northeastern Brazil
}

\author{
Max Anjos $1,2, * \mathbb{E}$, António Lopes ${ }^{2} \mathbb{D}$, Andrews José de Lucena ${ }^{3}$ and Francisco Mendonça ${ }^{1}$ \\ 1 Laboratory of Climatology, Department of Geography, Federal University of Paraná (UFPR), Rua XV de \\ Novembro, 1299-Centro, Curitiba 80060-000, Brazil; chico@ufpr.br \\ 2 Centre of Geographical Studies, Institute of Geography and Spatial Planning (IGOT), Universidade de Lisboa, \\ Rua Branca Edmée Marques, Cidade Universitária, 1600-276 Lisboa, Portugal; antonio.lopes@campus.ul.pt \\ 3 Department of Geography, Rural Federal University of Rio de Janeiro, Seropédica 23897-035, Brazil; \\ lucenageo@yahoo.com.br \\ * Correspondence: maxanjos@campus.ul.pt
}

Received: 2 September 2020; Accepted: 17 September 2020; Published: 22 September 2020

\begin{abstract}
Characterizing the behaviour of the sea breeze phenomenon is the foremost factor in the reduction in the heat stress and the achievement of the pleasant environment in coastal cities globally. However, this seminal study shows that the Sea Breeze Front (SBF) development can be related to an increase in outdoor thermal discomfort in a northeastern Brazilian city during summer. We explored the relationship between SBF and thermal comfort conditions using in situ meteorological observations, the SBF identification method, local climate zones (LCZs) classification, and the Physiological Equivalent Temperature (PET) thermal comfort index. SBF days and Non-SBF days were characterized in terms of weather conditions, combining meteorological data and technical bulletins. SBF days included hot and sunny days associated with the centre of the Upper Tropospheric Cyclonic Vortices (UTCV). In contrast, Non-SBF days were observed in UTCV's periphery because of cloudy sky and rainfall. The results showed that the mean temperature and PET in the SBF days were $2.0^{\circ} \mathrm{C}$ and $3.8^{\circ} \mathrm{C}$ higher, respectively, compared to Non-SBF days in all LCZ sites. The highest PET, of $40.0^{\circ} \mathrm{C}$, was found on SBF days. Our findings suggest that SBF development could be an aggravating factor for increasing heat stress of the people living in the northeastern coast of the Brazilian city, after SBF passage.
\end{abstract}

Keywords: see breeze front; outdoor thermal comfort; urban heat island; local climate zones

\section{Introduction}

“Let's go live up northeast, Anarina. I'll leave here my friends, my books, my possessions, my shame. You'll leave here your daughter, your grandmother, your husband, your lover. Here it's very hot. It's also hot up northeast. But there, there's breeze: We'll live on breeze, Anarina" [1] (translated by the authors). The many feelings and sensations illustrated in this poem by Manuel Bandeira offer us a common assumption of the well-being linked with the improvement of human thermal comfort conditions that the sea breeze can provide. Through a cooling air effect that drops temperature and increases humidity, sea breeze reduces the heat stress and contributes to achieving the pleasant thermal conditions in tropical coastal cities [2-4] However, a previous study suggested that the sea breeze development would enhance heat stress in the state of Sergipe, northeastern Brazil, due to an increase in mean air temperature and solar radiation [5]. The present study aims to evaluate the impact of sea breeze on outdoor thermal conditions in a coastal city of northeastern Brazil.

Thermal comfort is a condition in which the mind expresses satisfaction with the thermal environment [6]. It can be classified into three types, according to its environment [7]: Outdoor, 
semi-outdoor and indoor. The thermal sensation experienced by humans in outdoor urban space is subjectively assessed through combined approaches, such as in situ microclimatic measurements or questionnaire campaigns, in which a set of physical characteristics (e.g., sun and shade variations, wind, humidity and temperature changes) and human aspects (e.g., activities and metabolic heat production, previous experience and physical amenities) are measured in various environmental conditions [8-10]. The quantification of human thermal comfort conditions has been evaluated based on the bioclimatic/thermal indices, which combine both physical parameters and human factors of the thermal environment [11-13]. Makaremi et al. [14] investigated the human thermal conditions in Malaysia using Physiologically Equivalent Temperature (PET) and highlighted the shaded outdoor spaces' effects on heat stress levels. Frang et al. [15] analysed outdoor thermal variations in Guangzhou, China, by applying PET and Universal Thermal Climate Index (ITCI) indices. They demonstrated how these indices are sensitive to different factors (e.g., meteorological parameters, clothing insulation and metabolic rate). Hirashima et al. [16] evaluated daytime thermal conditions in Belo Horizonte, Brazil, by taking PET and reported people's adaptation and preferred experiences using a survey. A comprehensive catalogue of 162 thermal climate indices can be consulted in Freitas and Grigorieva [11].

In tropical coastlines, thermal comfort conditions are mostly influenced by a combination of high temperatures, low mean wind speed, and high humidity associated with high incidence of solar radiation, which are controlled by a range of synoptic and mesoscale systems [5].

Sea breeze is a well-known circulation mesoscale system induced by thermal contrast between land and sea that transfers the cool marine air inland $[17,18]$. The Sea Breeze Front (SBF) is one the components of the sea breeze system and is associated with temperature drop and humidity rise, in which the air is forced to ascend and condensate in low-level atmosphere, resulting in a line of clouds parallel to the shoreline $[18,19]$. A SBF and its advance inland occurs after a convergence of factors, such as intensity and direction of the synoptic-scale cross-shore flow, positive land-sea temperature difference, Coriolis force by rotating associated wind components, surface friction, and interaction with other weather systems [19]. Moreover, local aspects, such as the shape of the coastline with straight or relative to curvature flow direction and the size and shape of landmass (e.g., flat terrain) that provides low-friction pathways, also mediate the inland penetration of the SBF $[20,21]$.

The inland advancement of the SBF alters the cloudless sky conditions, modifying the radiative energy balance, and leads to changes in the amount of incoming solar radiation and wind patterns [22]. It also changes the amount of rainfall [23], and the transportation and dispersion of atmospheric constituents [24-26].

SBF extends for a $200 \mathrm{~km}$ wideband along the coastal areas of the world, where almost half the global population and most megacities are localized [27]. Urbanization and population growth have led to higher surface and air temperatures than those in the surrounding rural areas, commonly named Urban heat island (UHI). UHI affects human health and comfort [28], leading to reduced labour productivity [29]. The multiple interactions between sea breeze and UHI have been reported from various studies [22,23,30-36], which show that the cooling sea breeze effect reduces UHI intensity and improves outdoor thermal comfort in the cities. Sasaki et al. [37] analysed the relationship between SBF and temperature distribution in Japan using a combination of numerical simulations and field campaigns, and highlighted the effective mitigation of the sea breeze on summer days. Papanastasiou et al. [38] observed that the sea breeze lessened heatwave events in Athens, Greece, getting a substantial reduction of $4.0^{\circ} \mathrm{C}$ in temperature. Lopes et al. [39] demonstrated that most sites influenced by sea breeze had higher comfort conditions in Madeira Island, Portugal, during average days. Emmanuel and Johansson [2] reported that the absence of sea breeze contributes to an unpleasant thermal environment during hot afternoons in Colombo, Sri Lanka.

However, studies on increased temperature and adverse thermal comfort related to SBF are scarce. Zhou et al. [40] assessed the quantitative effect of sea breeze cooling in Adelaide, Australia. They observed that the mean air temperature in the days without sea breezes is lower than that with 
sea breezes due to thermal contrast between land and sea. A previous study conducted by Anjos and Lopes [5] in Sergipe State, Brazil, found that the SBF days are associated with an increase in the mean of solar radiation $\left(84 \mathrm{~W} \mathrm{~m}^{-2}\right)$ and air temperature $\left(1.0^{\circ} \mathrm{C}\right)$ after SBF passage. Based on this evidence, we hypothesize that SBF development is related to an increase in thermal discomfort in northeastern Brazilian cities. The purpose of our study was to test this hypothesis by exploring the relationship between SBF and outdoor thermal conditions in a mid-size city in northeastern Brazil. Thus, we aim to:

1. Apply a SBF day classification using an identification SBF method;

2. Pinpoint the weather conditions that favour the development of SBF;

3. Evaluate the outdoor thermal comfort conditions under SBF days and Non-SBF days using air temperature and thermal comfort index data from an urban meteorological network and Local Climate Zone classification.

This study offers an important additional scientific insight into the biometeorological and urban climatology field studies, in the assessment of sea breeze under outdoor thermal conditions in a tropical built environment. As far as we know, this is the first time that SBF is investigated as a meteorological factor for urban thermal comfort in Brazil using this integrated methodology.

\section{Methodology}

\subsection{Study Area}

Aracaju is located in Sergipe, on the northeast coast of Brazil $\left(10^{\circ} 51^{\prime}\right.$ and $11^{\circ} 07^{\prime} \mathrm{S}, 37^{\circ} 02^{\prime}$ and $37^{\circ} 09^{\prime} \mathrm{W}$ ) (Figure 1). The population is about 640,000 inhabitants and demographic density 3000 inhab. $/ \mathrm{km}^{2}$ [41]. The city has hot summers and cool winters. In summer (December-March), the mean monthly temperature is $27.3{ }^{\circ} \mathrm{C}$, insolation varies from 243 to $283.6 \mathrm{~h}$ of sunshine, and accumulated rainfall from 28 to $87.6 \mathrm{~mm}$; whilst in winter (April-July), the mean monthly temperature is $25.4{ }^{\circ} \mathrm{C}$, insolation goes 177.4 to $217.6 \mathrm{~h}$ of sunshine, and accumulated rainfall from 174.2 to $241.8 \mathrm{~mm}$ [42].

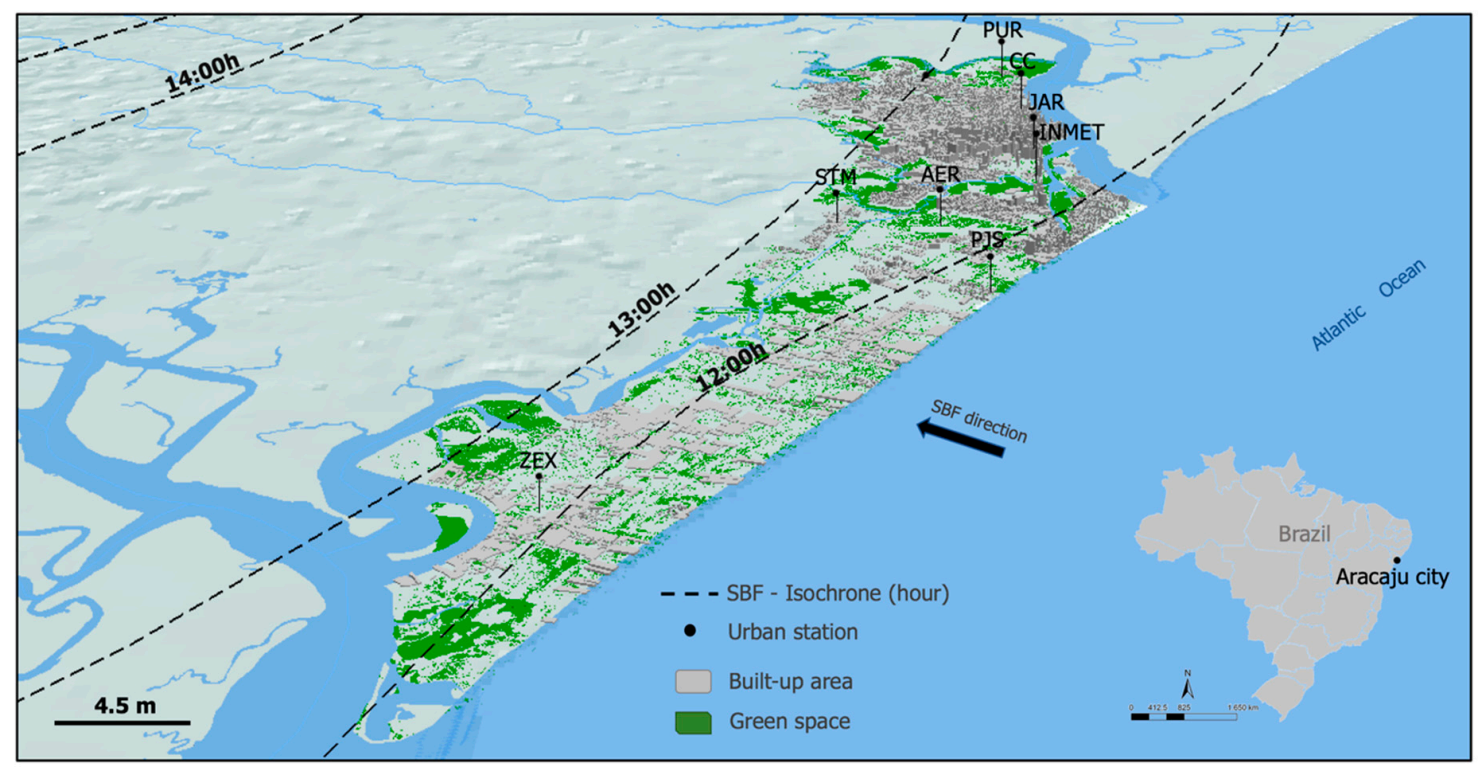

Figure 1. Geographical location of Aracaju city in Brazil and spatial distribution of the measured sites in the study area. The dashed black lines represent the hourly isochrones of the SBF in Sergipe (Hourly isochrones expressed in term of Coordinated Universal Time, UTC-3, three hours less than local zone time). Additional information about these isochrones can be consulted in Anjos and Lopes [5].

Since Aracaju has a tropical position, $35.44 \mathrm{~km}$ of coastline and gentle plain up to $100 \mathrm{~m}$ above mean sea level; it is exposed to a range of tropical and subtropical meteorological systems, such as Upper 
Tropospheric Cyclonic Vortices (UTCV), South Atlantic Subtropical Anticyclone (SASA), trade winds, troughs in the middle troposphere, and Mesoscale Convective Complexes (MCC). These phenomena largely influence the local climate and weather, as well as the inland penetration of the SBF [5].

\subsection{Monitoring Air Temperature Data and Local Climate Zones}

We used the hourly air temperature data from 1 December 2014 to 31 March 2015 (hereafter referenced as summer 2015). Anjos and Lopes [5] previously reported the SBF development over the study area in summer 2015 due to the intensity of the thermal gradient between continent and ocean. Air temperature data were extracted from a field campaign conducted by Anjos and Lopes [43] and Anjos et al. [44] to evaluate the UHI intensity in Aracaju. We selected six sensors with built-in data loggers and housed in a shield (HOBO U23 Pro v2 Temperature/Relative Humidity, Onset ${ }^{\circledR}$, EUA), that has an accuracy of $\pm 0.21^{\circ} \mathrm{C}$ in the range of 0 to $+50.0^{\circ} \mathrm{C}$. All sensors were deployed on lampposts at $3.5 \mathrm{~m}$ above the ground. To ensure local scale representativeness of air temperature data, we adopted the Local Climate Zones (LCZs) classification, which consists of regions of uniform surface cover (pervious and impervious), structure (density and geometric aspects of the buildings), fabric (albedo, thermal admittance), and human activity that span hundreds of meters to several kilometers in the horizontal scale [45]. Several studies have investigated the influences of land use and cover on the behavior of the UHI using LCZs classification [46-49]. The LCZs mapping procedure of Aracaju can be consulted in Anjos and Lopes [43]. Six LCZs were selected as follows: LCZ 3-Compact low-rise, LCZ 4-Open high-rise, LCZ A-Dense trees, LCZ 7-Lightweight low-rise, LCZ 6-Open low-rise, LCZ 9-Sparsely built. The main physical proprieties of urban stations and localization of LCZs are presented in Figure 2 and Table 1.

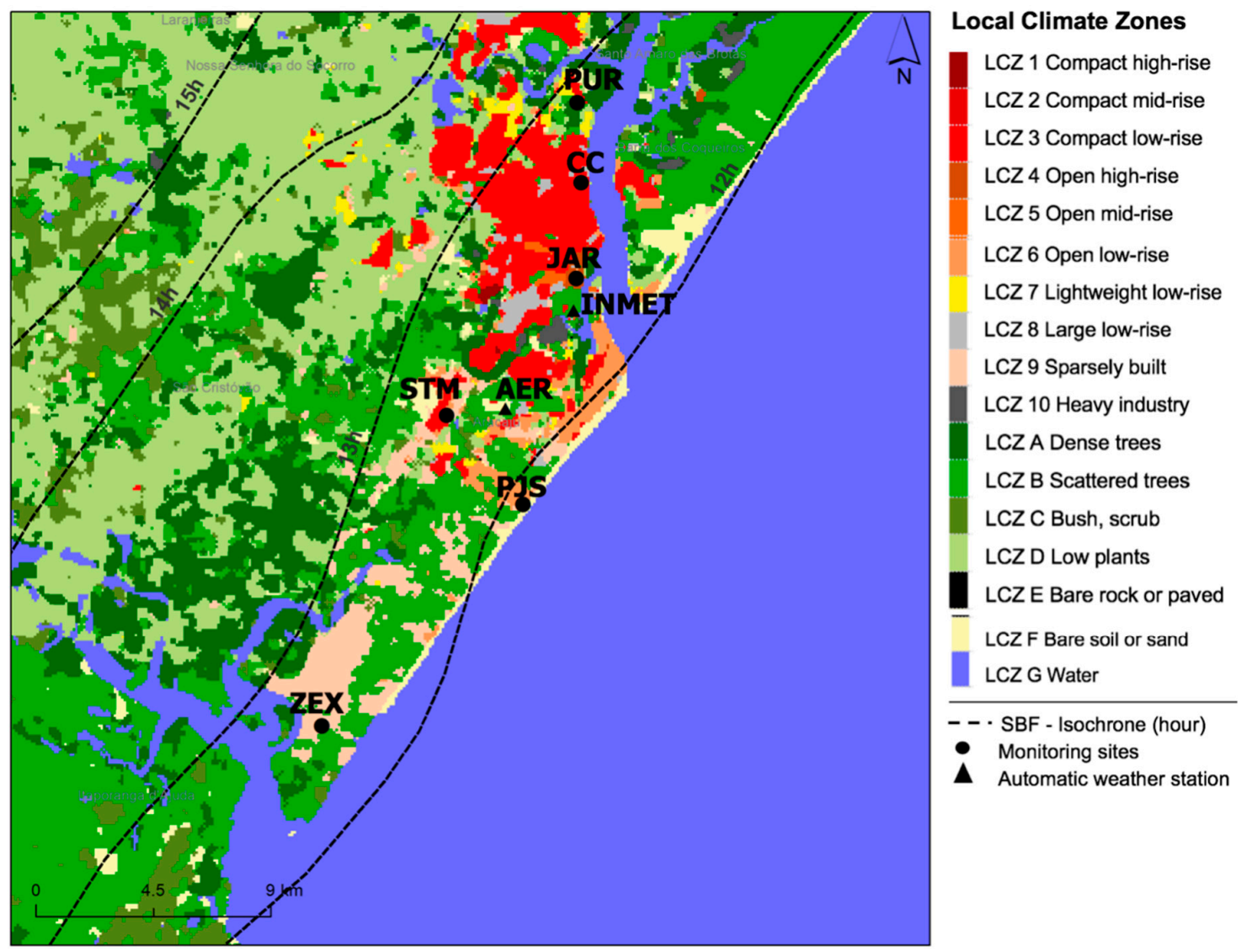

Figure 2. LCZ map of Aracaju, modified from Anjos and Lopes [43], spatial distribution pf the monitored sites, and hourly isochrones of the SBF (dashed black lines) according to Anjos and Lopes [5]. 
Table 1. Site metadata for urban meteorological network and LCZs (adapted from Anjos and Lopes [43]).

\begin{tabular}{|c|c|c|c|c|c|c|c|c|c|}
\hline \multirow[b]{2}{*}{ Urban Station (Sensor) } & \multirow[b]{2}{*}{ LCZ Types } & \multicolumn{8}{|c|}{ Local Scale $^{1}$} \\
\hline & & $\begin{array}{c}\mathrm{SVF}^{2} \\
(0-1)\end{array}$ & $\begin{array}{c}\text { BSR }^{3} \\
(\%)\end{array}$ & $\begin{array}{c}\text { ISR }^{4} \\
(\%)\end{array}$ & $\begin{array}{l}\text { VR }^{5} \\
(\%)\end{array}$ & $\begin{array}{l}Z_{0}{ }^{6} \\
(\mathrm{~m})\end{array}$ & $\begin{array}{l}\mathrm{Z}_{\mathrm{d}}{ }^{7} \\
(\mathrm{~m})\end{array}$ & $\begin{array}{c}\mathrm{Z}_{\mathrm{H}}{ }^{8} \\
(\mathrm{~m})\end{array}$ & Aerial Photo of Urban Station \\
\hline PUR & $\begin{array}{l}\text { Dense trees } \\
(\mathrm{LCZ} \text { A) }\end{array}$ & 0.948 & 5.5 & 7.5 & 73 & 0.6 & 19.7 & 0.4 & \\
\hline $\mathrm{CC}$ & $\begin{array}{l}\text { Compact low-rise } \\
\text { (LCZ 3) }\end{array}$ & 0.708 & 69 & 93 & 2.3 & 1 & 9.8 & 10 & \\
\hline JAR & $\begin{array}{l}\text { Open high-rise } \\
\text { (LCZ 4) }\end{array}$ & 0.768 & 60 & 70 & 12 & 2 & 20 & 16 & \\
\hline STM & $\begin{array}{l}\text { Lightweight low-rise } \\
\text { (LCZ 7) }\end{array}$ & 0.953 & 25 & 50 & 9.5 & 0.3 & 9 & 5.8 & \\
\hline
\end{tabular}


Table 1. Cont

\begin{tabular}{|c|c|c|c|c|c|c|c|c|c|}
\hline \multirow[b]{2}{*}{ Urban Station (Sensor) } & \multirow[b]{2}{*}{ LCZ Types } & \multicolumn{8}{|c|}{ Local Scale $^{1}$} \\
\hline & & $\begin{array}{c}\text { SVF }^{2} \\
(0-1)\end{array}$ & $\begin{array}{c}\text { BSR }^{3} \\
(\%)\end{array}$ & $\begin{array}{c}\text { ISR }^{4} \\
(\%)\end{array}$ & $\begin{array}{l}\text { VR }^{5} \\
(\%)\end{array}$ & $\begin{array}{l}Z_{0}{ }^{6} \\
(\mathrm{~m})\end{array}$ & $\begin{array}{l}\mathrm{Z}_{\mathrm{d}}{ }^{7} \\
(\mathrm{~m})\end{array}$ & $\begin{array}{c}\mathrm{Z}_{\mathrm{H}}{ }^{8} \\
(\mathrm{~m})\end{array}$ & Aerial Photo of Urban Station \\
\hline PJS & $\begin{array}{l}\text { Open low-rise } \\
\text { (LCZ 6) }\end{array}$ & 0.965 & 12 & 23 & 6 & 0.25 & 3.7 & 6.7 & \\
\hline ZEX & $\begin{array}{l}\text { Sparsely built } \\
\text { (LCZ 9) }\end{array}$ & 0.981 & 50 & 48 & 26 & 0.1 & 1.6 & 6.5 & \\
\hline
\end{tabular}

${ }^{1}$ Physical proprieties were measured within circles of $500 \mathrm{~m}$ radius around each temperature sensor in the canopy layer. ${ }^{2}$ SVF-Sky View Factor (including vegetation and buildings); ${ }^{3} \mathrm{BSR}$ - built-up surface ratio; ${ }^{4} \mathrm{VR}$ —vegetation ratio; ${ }^{5} \mathrm{ISR}$-impervious surface ratio; ${ }^{6} \mathrm{Z}_{0}$ —Roughness length; ${ }^{7} \mathrm{Z}_{\mathrm{d}}$-Zero-plane displacement; ${ }^{8} \mathrm{Z}_{\mathrm{H}}$ - height of roughness elements (excluding vegetation). 


\subsection{Thermal Comfort Index}

We quantified the thermal biometeorological conditions by using hourly mean Physiological Equivalent Temperature (PET) data in the sampling period. PET expresses the air temperature at which the energy balance of the human body for a typical indoor condition is balanced by the skin temperature, core temperature and sweat rate as equal to the actual outdoor conditions [50]. The indoor conditions are assumed to be the mean radiation temperature of the environment equaling the air temperature, wind speed calm of $0.1 \mathrm{~ms}^{-1}$, and vapor pressure $12.0 \mathrm{hPa}$. The PET values indicate, in equivalent degree Celsius, the thermal perception by the human body using skin temperature and core temperature according to the Munich Energy Balance Model for Individuals (MEMI) [50].

To calculate the hourly PET values at each LCZ measurement site, we used the RayMan ${ }^{\circledR}$ software $[51,52]$ that has as inputs meteorological parameters and human factors. The former was the mean hourly air temperature from a field campaign and the mean hourly global radiation, relative humidity, and wind speed from the INMET station (MAWS301, Vaisala ${ }^{\circledR}$, Helsinki, Finland) managed by the Brazilian National Meteorological Weather Institute. To calculate PET, all meteorological parameters should be measured at a human-biometeorologically significant height of $1.1 \mathrm{~m}$ above ground, which is the average height of a standing person's centre of gravity in Europe [53]. We adopted the human-biometeorologically significant height of $1.73 \mathrm{~m}$ above the ground $\left(v_{1.73}\right)$ to represent the average height of a Brazilian man [50]. Moreover, several PET field observations (e.g., [54]) have been conducted under different heights in the air layer between the urban surface and the mean roof-height, commonly referred to as the Urban Canopy Layer (UCL) [55]. All meteorological parameters of this study were measured at the height of $2.0-3.5 \mathrm{~m}$ to evaluate the thermal variations into the UCL, except the wind data measured at $10 \mathrm{~m}$. In order to obtain wind data as representative of the UCL, we thus calculated the mean hourly wind speed values to the Brazilian human-biometeorologically significant height of $1.73 \mathrm{~m}\left(v_{1.73}\right)$, following the equation [56]:

$$
v_{1.73}=v_{\mathrm{h}}(1.73 / \mathrm{h})^{\alpha}, \alpha=0.12 \mathrm{z}_{0}+0.18,
$$

where $v_{h}$ is the wind speed $\left(\mathrm{m} \mathrm{s}^{-1}\right)$ at a height $h$ of $10 \mathrm{~m}, \alpha$ is the empirical exponent, and $\mathrm{z}_{0}$ is the aerodynamic roughness length (m). We obtained an $\alpha$ of 0.21 by using a mean of $25 \mathrm{~m}$ of $\mathrm{z}_{0}$ retrofitted from Anjos [57]. As a result of Equation 1, the mean diurnal cycles of the $v_{1.73}$ showed a reduction of $1.0 \mathrm{~m} \mathrm{~s}^{-1}$ compared to wind speed measured at $10 \mathrm{~m}$, the difference ranging from $0.6 \mathrm{~m} \mathrm{~s}^{-1}$ at $06: 00$ to $1.4 \mathrm{~m} \mathrm{~s}^{-1}$ at 15:00. We assume that the correction of wind speed data reflects the common flow patterns across the different LCZs in the surveyed area.

The human factors were personal data (e.g., a 35-year-old man, weighing $75.0 \mathrm{~kg}$ and $1.73 \mathrm{~m}$ in stature), clothing and activity (e.g., standing, internal heat production of 80 Watts, clothing that has a heat transfer resistance of 0.5 clo).

\subsection{Identification of SBF Days}

The identification of SBF days was retrofired by Anjos and Lopes [5], who created a climatology of the SBF based on in situ meteorological and satellite image data for the Sergipe region, where the study area is localized. This SBF climatology includes the onset, cessation, duration, strength, inland penetration, and classification of SBF and Non-SBF days in summer 2015. Here, we sampled 121 days, with 67 being classified as SBF and 54 as Non-SBF.

Subsequently, the diurnal cycle of air temperature and PET values at each LCZ measurement site were compared to SBF days and Non-SBF days. We adopted the PET classes proposed by Souza [58] as thermal perception and physiological stress (Table 2). The ranges of PET values correspond to the thermal experience of a specific individual group using questionnaires and meteorological field campaigns in open urban spaces in Salvador, a coastal city of northeastern Brazil [58], which has similar hot and humid conditions to the study area. Hence, the thermal perception of those PET classes 
in the Table 2 may diverge from other cities, considering different types of climate, weather settings, urban morphologies and geographic locations [12,59].

Table 2. Ranges of PET values for different thermal perceptions and physiological stress on human species (adapted from Souza [58]).

\begin{tabular}{ccc}
\hline PET & Thermal Perception & Grade of Physiological Stress \\
\hline$<18.0^{\circ} \mathrm{C}$ & Cool & Strong cool stress \\
$18.0^{\circ} \mathrm{C} \mathrm{a} 26.0^{\circ} \mathrm{C}$ & Slightly cool & Slight cool stress \\
$26.0^{\circ} \mathrm{C}$ a $29.0^{\circ} \mathrm{C}$ & Comfortable & No thermal stress \\
$29.0{ }^{\circ} \mathrm{C}$ a $34.0^{\circ} \mathrm{C}$ & Hot & Moderate heat stress \\
$>34.0{ }^{\circ} \mathrm{C}$ & Very hot & Strong heat stress \\
\hline
\end{tabular}

\subsection{Characterization of Weather Conditions}

The weather conditions of the SBF days and Non-SBF days were characterized using mean hourly values of air temperature, relative humidity, atmospheric pressure, wind speed, and hourly cumulative values of solar radiation and rainfall measured at the INMET station. The sky conditions data were collected from the AER station (Figure 1) in the Meteorological Aviation Report (METAR) format, which contains a set of meteorological variables and weather information [60]. Four types of sky conditions were retrofired from METAR and defined as follows: clear sky (0 octas); partly cloudy (from $1 / 8$ to $4 / 8$ octas); very cloudy (from $5 / 8$ to $7 / 8$ octas); overcast sky ( 8 octas).

Subsequently, we matched the SBF days and Non-SBF days with weather systems observed over the study area in the sampled period. To identify the weather systems, we used the daily technical bulletin produced by the Brazilian Center for Weather Forecasting and Climate Studies (CPETEC/ INPE) [61]. A technical bulletin consists of daily synoptic analysis based on satellite imageries from Geostationary Operational Environmental Satellite (GOES) 16 with $10.3 \mu \mathrm{m}$ infrared and enhanced true colour (RGB), as well as charts of 250,500, $850 \mathrm{hPa}$ geopotential heights and surface-level pressure over South America at 00:00 and at 16:00 UTC. The main weather systems were as follows:

1. Upper Tropospheric Cyclonic Vortices (UTCV) is the system that usually occurs more strongly in the warmest months of the year, with an average lifetime varying from 4 to 11 days [62]. The movement location of the UTCV influences the cloudiness pattern in Northeastern Brazil [63].

2. Troughs are regions of relatively low pressure that regularly act along UTCV in Northeastern Brazil.

3. South Atlantic Subtropical Anticyclone (SASA) is a type of anticyclone, migratory or semi-permanent, associated with subsidence, low-level divergence, and rotational wind. It has a center characterized by a region of calm and more intense winds in their borders [64]. The SASA is often associated with Southeast and Northeast trade winds in Northeastern Brazil.

4. Mesoscale Convective Complexes (MCCs) are the largest of the convective storms; their form is a cumulonimbus cloud system that produces widespread precipitation in different regions of the globe [65] and has been associated with thunderstorm events in Northeastern Brazil [66].

\section{Results and Discussion}

\subsection{Weather Conditions of SBF Days and Non-SBF Days}

The weather conditions of the SBF days and Non-SBF days are characterized by mean diurnal cycles of six meteorological variables (Figure 3) and by the frequency of sky conditions and meteorological systems (Table 3). The Atlantic Ocean's east setting, and the regularity of trade winds throughout the year, shape the inland-city penetration of SBF. Figure 3a shows that the mean wind direction (around $100^{\circ}$ ) and speed (maximum of $4.2 \mathrm{~ms}^{-1}$ at 13:00) were the same for SBF days and Non-SBF days from morning (09:00) to evening (03:00). Thus, the SBF did not exhibit a significant shift in wind direction and speed, suggesting that the SBF and trade winds acted together in the city. This same 
pattern was found by Anjos and Lopes [5] in Sergipe state in summer 2015. This unchanged wind speed reveals that air temperature variations and the level of thermal sensation differences in Aracaju are attributable mostly to changes in solar irradiance as a consequence of the SBF development.



(a)

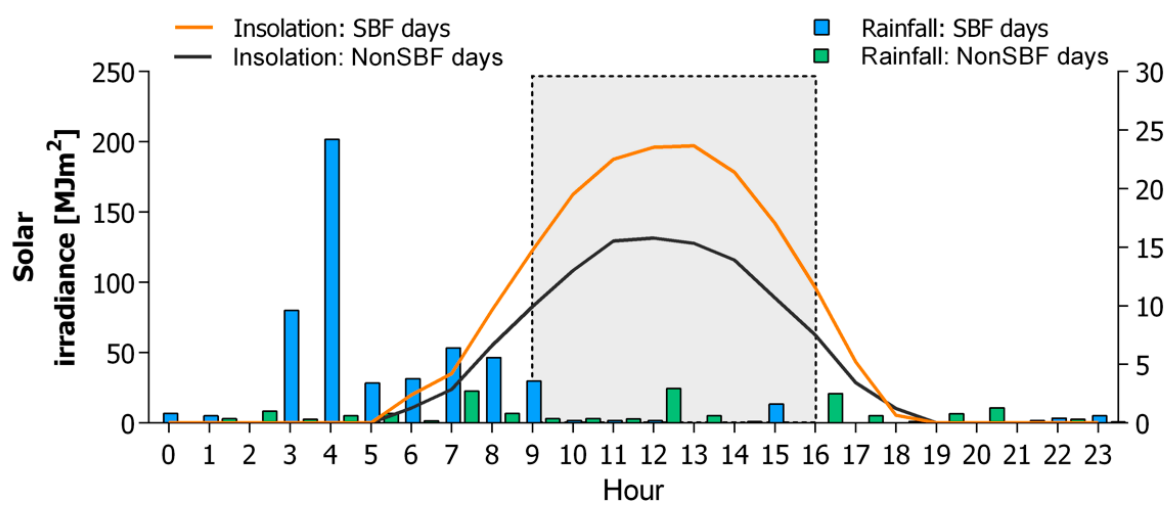

(b)

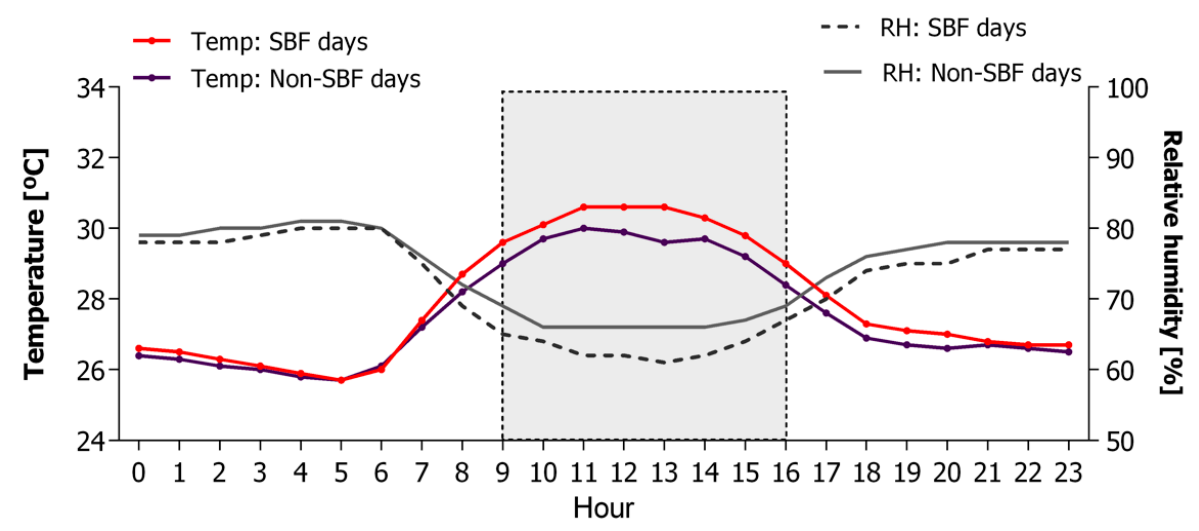

(c)

Figure 3. Mean diurnal cycles of six meteorological variables for SBF days and Non-SBF days (summer 2015): (a) wind speed and wind direction (wind speed values were recalculated to a height of $1.73 \mathrm{~m}$ above the ground); (b) solar irradiance and total accumulated rainfall; (c) air temperature and relative humidity. SBF duration (09:00-16:00) is represented by the hatched grey area according to Anjos and Lopes [5]. 
Table 3. Details of sky conditions and meteorological systems for SBF days and Non-SBF days.

\begin{tabular}{cccc}
\hline \multirow{2}{*}{ Variables } & & SBF Days & Non-SBF Days \\
\cline { 3 - 4 } & & Frequency & Frequency \\
\cline { 3 - 4 } Sky conditions & Clear sky & $8 \%$ & $7 \%$ \\
& Partly cloudy & $89 \%$ & $78 \%$ \\
& Very cloudy & $3 \%$ & $15 \%$ \\
& Overcast sky & $0 \%$ & $0 \%$ \\
\hline \multirow{3}{*}{ Meteorological systems } & UTCV & $81 \%$ & $41 \%$ \\
& Troughs & $9 \%$ & $13 \%$ \\
& SASA & $10 \%$ & $10 \%$ \\
& MCCs & $0 \%$ & $12 \%$ \\
\hline
\end{tabular}

SBF days presented hotter and sunnier conditions associated with increased mean dose of solar irradiance and air temperature, with a maximum difference of $60 \mathrm{MJ} \mathrm{m}^{2}$ and $1.0{ }^{\circ} \mathrm{C}$ at $13: 00$, respectively, compared to Non-SBF days (Figure 3b). Under these circumstances, the relative humidity was up to $10 \%$ lower during SBF days. SBF hot days are related to clear sky caused by advances of inland cloudy line passage that implies more considerable penetration of direct shortwave radiation surface, contributing positively to the higher air temperature.

Most SBF days featured partly cloudy (89\%) and clear sky ( $8 \%$ ) conditions linked with UTCV $(81 \%, 56$ events), SASA (10\%) and Troughs ( $9 \%)$, whereas Non-SBF days were from partly cloudy $(78 \%)$ to very cloudy $(15 \%)$ with UTCV (41\%), Troughs (13\%) and MCCs (12\%) (Table 3). Note that the SBF development in hot and sunny days was observed on the UTCV's centre, defined by clear sky due to downward motion, whilst UTCV's periphery made SBF formation difficult because of cloudy sky and rainfall events caused by upward motion. Most total accumulated rainfall (Figure 3c) occurred in the night and morning with a maximum of $25 \mathrm{~mm}$ at 04:00 on SBF days due to UTCV. These results are consistent with those found by Gan and Kousky [63] and Lyra [66], who reported that UTCV and MCCs produce rainfall and thunderstorm events in northeastern Brazil.

\subsection{SBF and Local Climates}

Figure 4 presents the diurnal patterns of the mean air temperature at six LCZs under SBF days and Non-SBF days. The inter-site air temperature difference was slightly homogenized between LCZ 3 (CC) and LCZ 4 (JAR), localized in the central area, with medium urban densities and the LCZ 9 (ZEX), LCZ 7 (STM) and LCZ 6 (PJS) situated in the peripheric areas with low built-up and impervious fractions. However, Figure 4 shows that the mean temperatures on SBF days were higher than on Non-SBF days in all LCZs sites during the afternoon, suggesting clear evidence of SBF passage effect on the increased mean temperature. This is attributed to changes in the nebulosity pattern caused by inland penetration of SBF, which creates a clear sky region behind the head of the front and a cloudy one ahead of it. These clear sky conditions facilitate the penetration of direct shortwave radiation onto the urban and rural surfaces. This radiation is rapidly stored and reradiated as long-wave radiation during the day. Zhou et al. [40] also found a larger mean temperature difference of $\sim 2.5^{\circ} \mathrm{C}$ at $14: 00$ for sea breeze days in Adelaide, Australia, using field observation. It was attributed to a greater land-sea temperature contrast during summer. 


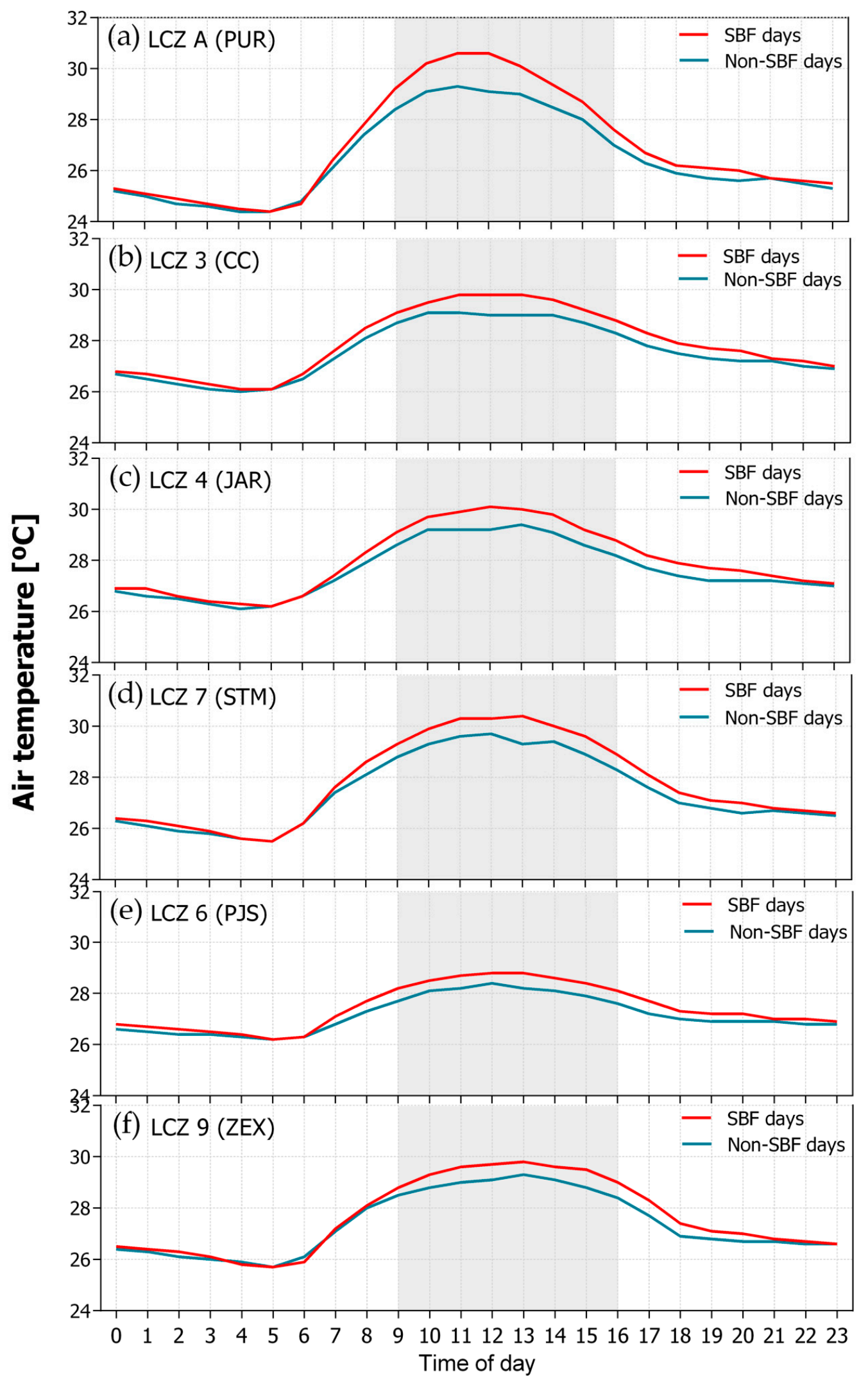

Figure 4. Diurnal patterns of mean air temperature at the six measurement LCZ sites, under SBF days and Non-SBF days in summer 2015: (a) LCZ A (PUR); (b) LCZ 3 (CC); (c) LCZ 4 (JAR); (d) LCZ 7 (STM); (e) LCZ 6 (PJS); (f) LCZ 9 (ZEX). SBF duration (09:00-16:00) is represented by the grey area according to Anjos and Lopes [5]. 
The largest air temperature difference occurred in LCZ A (PUC), with a maximum of $2.0^{\circ} \mathrm{C}$ at 12:00 on SBF days (Figure 4a). A possible explanation for higher temperature at PUC is that the sensor is situated on an open space in an urban park (SVF > 0.90), being more exposition to high solar irradiance on SBF days, and surrounded by dense trees $(73 \%)$ that reduce wind speeds and trammels the transfer of heat away from the park.

The lowest difference during the SBF duration, of $0.5^{\circ} \mathrm{C}$, was observed near ocean in LCZ 6 (PJS), where the water bodies and cooling air from natural ventilation are more efficient in lowering air temperature (Figure 4e). This behaviour at PUC and PJS has been found by Anjos and Lopes [5] in Aracaju during a hot seasonal afternoon. A descriptive statistic of air temperature on SBF days and Non-SBF days per LCZ is illustrated in Table 4.

Table 4. Details of air temperature for SBF days and Non-SBF days.

\begin{tabular}{|c|c|c|c|c|c|c|c|c|}
\hline \multirow{3}{*}{$\begin{array}{c}\text { LCZ Class } \\
\text { (Urban Station) }\end{array}$} & \multicolumn{8}{|c|}{ Air Temperature $\left({ }^{\circ} \mathrm{C}\right)$} \\
\hline & \multicolumn{4}{|c|}{ SBF Days } & \multicolumn{4}{|c|}{ Non-SBF Days } \\
\hline & Mean & Min & Max & $\pm \mathrm{SD}^{1}$ & Mean & Min & Max & \pm SD \\
\hline LCZ 3 (CC) & 27.8 & 23.7 & 31.2 & 1.401 & 27.5 & 23.8 & 30.8 & 1.365 \\
\hline LCZ 4 (JAR) & 27.9 & 23.4 & 31.6 & 1.472 & 27.6 & 23.6 & 31.4 & 1.417 \\
\hline LCZ 9 (ZEX) & 27.6 & 23.2 & 31.0 & 1.580 & 27.3 & 23.2 & 30.9 & 1.530 \\
\hline LCZ 7 (STM) & 27.7 & 23.5 & 32.4 & 1.788 & 27.4 & 23.1 & 31.6 & 1.686 \\
\hline LCZ 6 (PJS) & 27.4 & 23.7 & 30.2 & 1.104 & 27.1 & 23.3 & 29.9 & 1.108 \\
\hline LCZ A (PUR) & 26.9 & 22.0 & 32.4 & 2.235 & 26.4 & 22.6 & 32.0 & 1.983 \\
\hline
\end{tabular}

\subsection{SBF and Thermal Biometeorological Conditions}

To demonstrate the evidence for a SBF effect on thermal comfort, the mean diurnal cycles of PET and the relative frequency of PET classes at six LCZs, divided into SBF days and Non-SBF days, are shown in Figures 5 and 6, respectively. The typical diurnal variation of thermal perception of people by PET values was as follows: The slightly cool class starts at 17:00 and remains until 06:00; after that, PET rises abruptly due to the increasing solar radiation and the heat stored in the ground, and reaches the hot and very hot classes $\left(\mathrm{PET}>29.0^{\circ} \mathrm{C}\right.$ ) in afternoon. Note that PET values were higher on SBF days than on Non-SBF days in all LCZs during the afternoon, with a large mean difference of $3.8^{\circ} \mathrm{C}$ in LCZ A (PUC) at 13:00 (Figure 5a). The highest PET, of $40.0^{\circ} \mathrm{C}$, was observed in PUC at 14:00 on SBF days and it is close to the highest PET value $\left(45.0^{\circ} \mathrm{C}\right)$ found by Andrade et al. [67] at an urban site in Salvador, Brazil.

We observed that, overall, PET class frequencies ranged from $62 \%$ for slightly cool to $1 \%$ for cool on both SBF and Non-SBF days. During SBF days, the frequencies of the slightly cool and comfortable classes were reduced $(-3 \%)$ compared to Non-SBF days, whilst they increased for hot and very hot classes (up to 7\%) in all LCZs (Figure 6).

These results suggest that SBF development can potentialize heat stress of people in outdoor urban spaces during daytime, after being exposed to higher solar radiation and temperatures. As shown in Figure 3a, the permanence of the same wind speed regime on both SBF days and Non-SBF days contributed to thermal discomfort conditions in the LCZ sites. Moreover, the high daytime PET values depend on air temperature and the effects of multiple three-dimensional radiation fluxes from the lower atmosphere on human body balance, represented by mean radiant temperature. Anjos [57] previously reported mean radiant temperature influences on diurnal patterns of PET values in Aracaju, with a maximum of $53.0^{\circ} \mathrm{C}$ during summer afternoons. The mean radiant temperature influences on variation of daytime PET values have been discussed by Abreu-Harbich et al. [68] in Campinas, Brazil, and Ketterer and Matzarakis [69] in Stuttgart, Germany. 


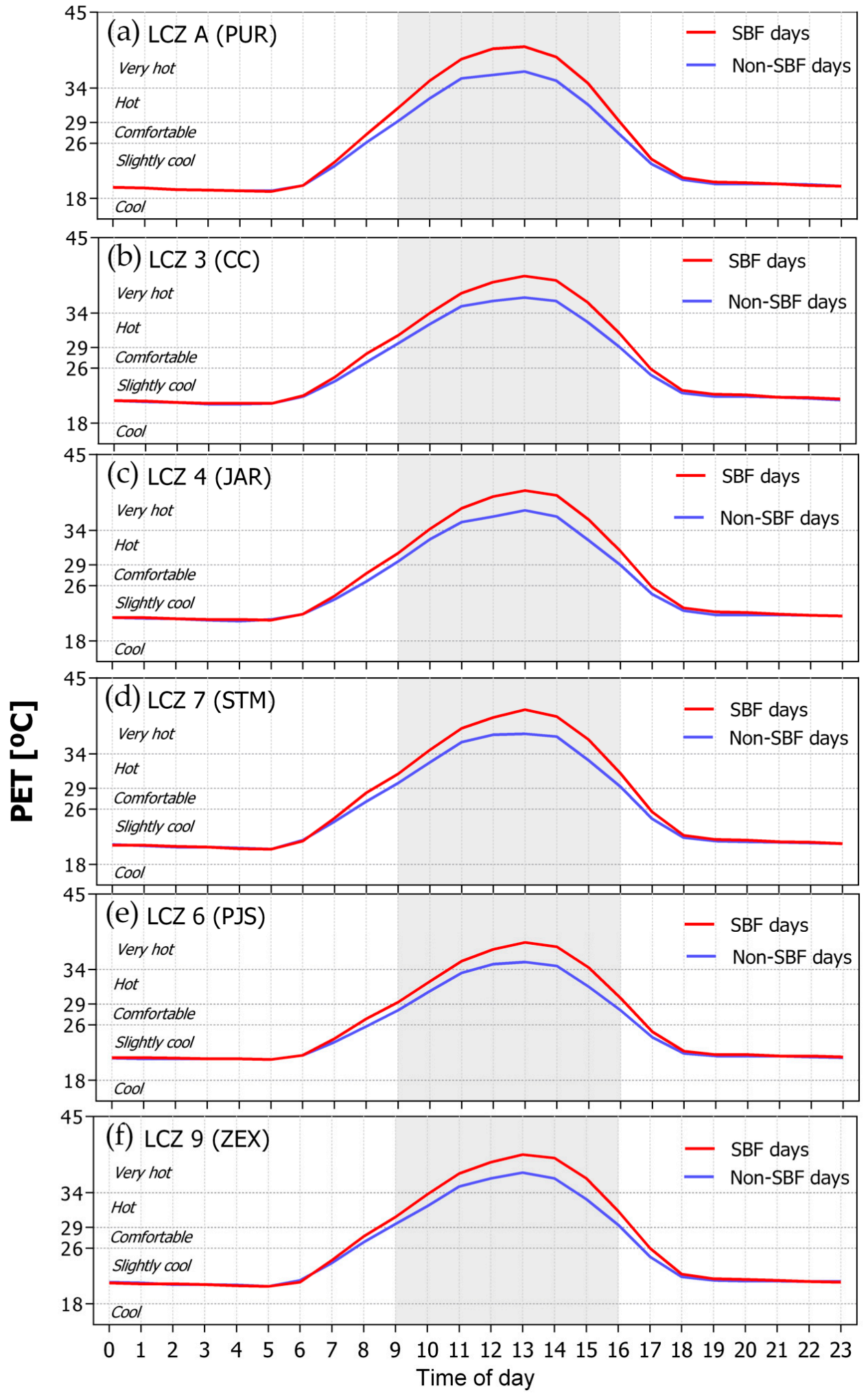

Figure 5. Diurnal patterns of mean PET values with PET classes at the six LCZ sites during SBF days and Non-SBF days in summer 2015: (a) LCZ A (PUR); (b) LCZ 3 (CC); (c) LCZ 4 (JAR); (d) LCZ 7 (STM); (e) LCZ 6 (PJS); (f) LCZ 9 (ZEX). SBF duration (09:00-16:00) is represented by the grey area according to Anjos and Lopes [5]. 
a)

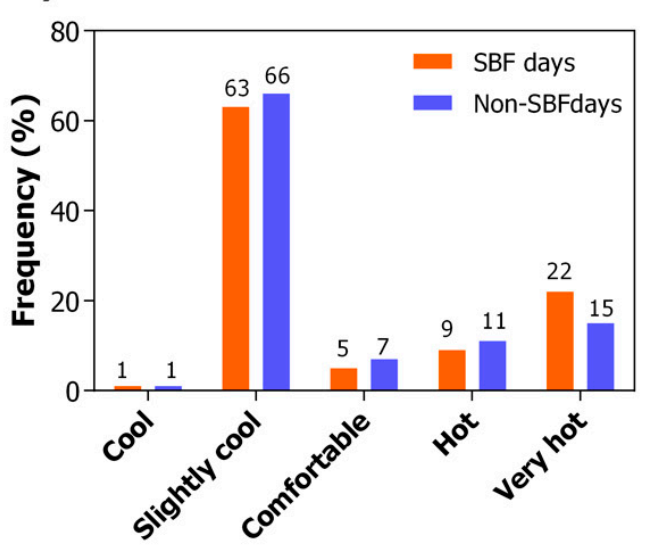

PET class $\left({ }^{\circ} \mathrm{C}\right)$

c)

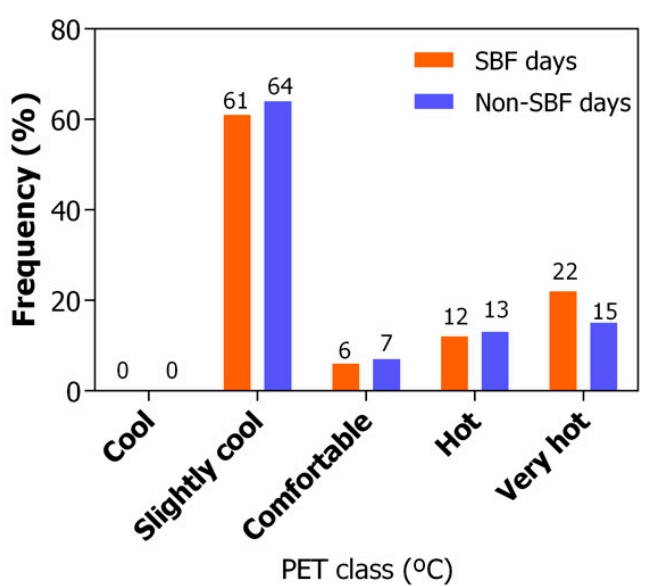

e)

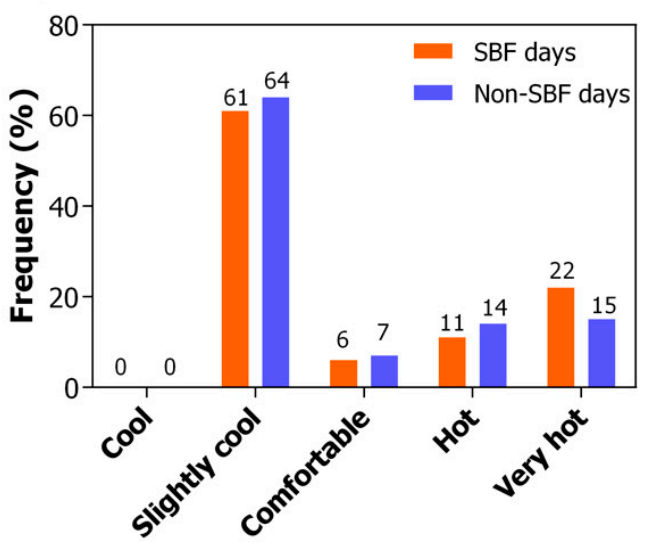

PET class $\left({ }^{\circ} \mathrm{C}\right)$ b) $\quad$ LCZ 3 (CC)



PET class $\left({ }^{\circ} \mathrm{C}\right)$

d)

LCZ 7 (STM)

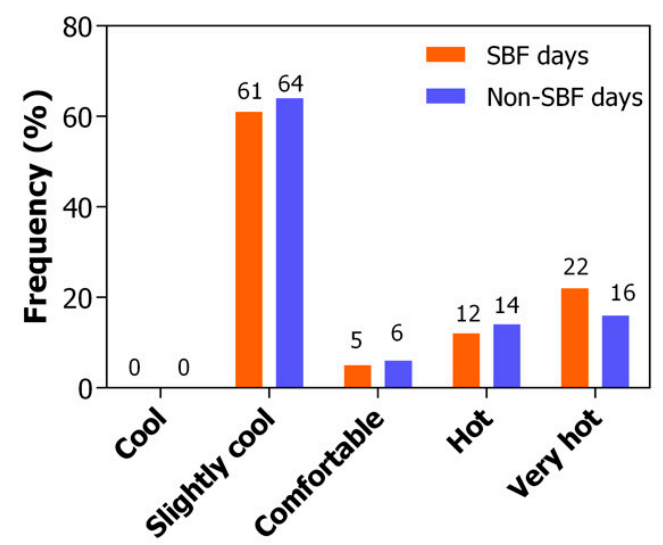

PET class $\left({ }^{\circ} \mathrm{C}\right)$

f) $\quad$ LCZ 6 (PJS)

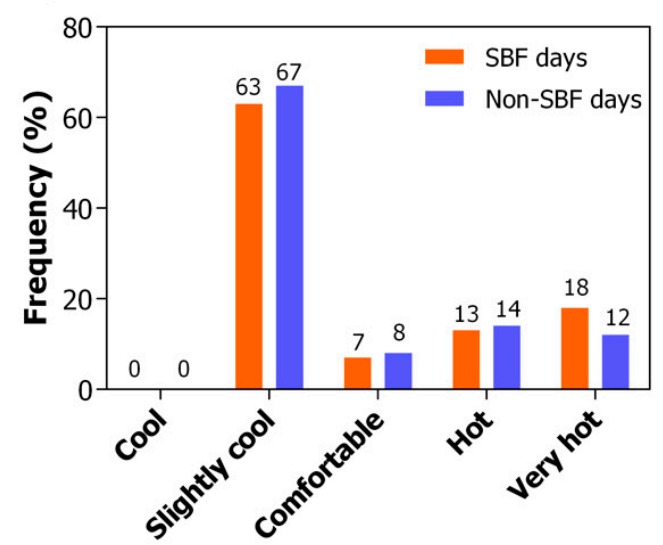

PET class $\left({ }^{\circ} \mathrm{C}\right)$

Figure 6. Relative frequency of PET classes at six LCZ sites during SBF days and Non-SBF days in summer 2015: (a) LCZ A (PUR); (b) LCZ 3 (CC); (c) LCZ 4 (JAR); (d) LCZ 7 (STM); (e) LCZ 6 (PJS); (f) LCZ 9 (ZEX). 


\section{Conclusions}

The relationship between SBF and outdoor thermal comfort was investigated using the in situ near-surface air temperature field, identification SBF method, LCZs classification, and PET. The most important and innovative conclusion of this work is that SBF development had a negative impact on outdoor thermal comfort. This differs from the common assumption, in science and common sense, that the cooling sea breeze has a positive role in the reduction in air temperature. We observed that mean temperature and PET values on SBF days were higher than on the Non-SBF days in all LCZ sites. This suggests also that SBF devolvement can potentialize the UHI intensity. Other considerations must be highlighted, such as the role of mesoscale phenomena in the configuration of SBF in Northeast Brazil, such as UTCV.

This paper represents an important biometeorological contribution to the atmosphere studies in tropical coastal cities in the Northeast of Brazil. In such cities, many human activities are mediated and guided by the presence of the sea, such as by the effect of breezes, which can influence economic, cultural and social well-being.

This study used air temperature data from six monitored LCZ sites in summer 2015. This same methodology could be used, in conjunction with questionnaires and meteorological field campaigns, to better understand the relationship between SBF and outdoor thermal comfort in different seasons. Another avenue for future research would be to evaluate the impact of SBF development on different age groups of the population pyramid, circumscribed by neighborhoods, for example. Such an endeavor could help define which humans and even social groups are most vulnerable to thermal stress and its possible consequences, and help inform government health policies. Finally, it is worth asking what the pattern of SBF on thermal comfort in other cities on the Brazilian coast might be. After all, Brazil is a country of continental dimensions with distinct coastal characteristics (e.g; due to topography and/or atmospheric systems) running from north to south. Understanding the dynamics of the sea breeze and its effect on outdoor thermal comfort is thus a major challenge in a country of the size and heterogeneity of Brazil, but nonetheless an undertaking of worthy of the endeavor.

Author Contributions: Conceptualization, M.A., A.L., A.J.d.L. and F.M.; methodology, software, and data curation, M.A., and A.L.; writing-original draft preparation, M.A., A.L., A.J.d.L.; writing一review and editing, M.A., A.L., A.J.d.L. and F.M.; funding acquisition, A.L., and F.M. All authors have read and agreed to the published version of the manuscript.

Funding: This research was funded by Fundação da Universidade Federal do Paraná (UFPR)/FUNPAR and Universidade de Lisboa, Institute of Geography and Spatial Planning (IGOT), Centre of Geographical Studies.

Acknowledgments: Max Anjos held a post-doctoral fellowship with PRINT/CAPES (Brazilian Ministry of Education) and CNPQ/MCTIC (Brazilian Ministry of Science, Techonolgy and Comunication). The authors would like to thank Alyson Fortuna, who operated the air temperature field campaign.

Conflicts of Interest: The authors declare no conflict of interest.

\section{References}

1. Bandeira, M. Belo Belo, 1st ed.; Global: São Paulo, Brazil, 2014.

2. Emmanuel, R.; Johansson, E. Influence of urban morphology and sea breeze on hot humid microclimate: The case of Colombo, Sri Lanka. Clim. Res. 2006, 30, 189-200. [CrossRef]

3. $\mathrm{Ng}$, E. Policies and technical guidelines for urban planning of high-density cities-Air ventilation assessment (AVA) of Hong Kong. Build. Environ. 2009, 44, 1478-1488. [CrossRef] [PubMed]

4. Emmanuel, R. Achieving thermal pleasure in tropical urban outdoors. In Urban Climate Challenges in the Tropics; Imperial College Press: London, UK, 2016; pp. 31-47.

5. Anjos, M.; Lopes, A. Sea breeze front identification on the northeastern coast of Brazil and its implications for meteorological conditions in the Sergipe region. Theor. Appl. Climatol. 2019, 137, 2151-2165. [CrossRef]

6. ANSI/ASHRAE Standard 55. Thermal Environmental Conditions for Human Occupancy; ASHRAE Inc.: Atlanta, GA, USA, 2010. 
7. Rupp, R.F.; Vásquez, N.G.; Lamberts, R. A review of human thermal comfort in the built environment. Energy Build. 2015, 105, 178-205. [CrossRef]

8. Nouri, A.S.; Charalampopoulos, I.; Matzarakis, A. Beyond Singular Climatic Variables-Identifying the Dynamics of Wholesome Thermo-Physiological Factors for Existing/Future Human Thermal Comfort during Hot Dry Mediterranean Summers. Int. J. Environ. Res. Public Health 2018, 15, 2362. [CrossRef]

9. Santos Nouri, A.; Matzarakis, A. The Maturing Interdisciplinary Relationship between Human Biometeorological Aspects and Local Adaptation Processes: An Encompassing Overview. Climate 2019, 7, 134. [CrossRef]

10. Chen, L.; $\mathrm{Ng}, \mathrm{E}$. Outdoor thermal comfort and outdoor activities: A review of research in the past decade. Cities 2012, 29, 118-125. [CrossRef]

11. De Freitas, C.R.; Grigorieva, E.A. A comprehensive catalogue and classification of human thermal climate indices. Int. J. Biometeorol. 2015, 59, 109-120. [CrossRef]

12. Matzarakis, A.; Mayer, H.; Iziomon, M.G. Applications of a universal thermal index: Physiological equivalent temperature. Int. J. Biometeorol. 1999, 43, 76-84. [CrossRef]

13. Jendritzky, G.; De Dear, R.; Havenith, G. UTCI-Why another thermal index? Int. J. Biometeorol. 2012, 56, 421-428. [CrossRef]

14. Makaremi, N.; Salleh, E.; Jaafar, M.Z.; GhaffarianHoseini, A. Thermal comfort conditions of shaded outdoor spaces in hot and humid climate of Malaysia. Build. Environ. 2012, 48,7-14. [CrossRef]

15. Fang, Z.; Lin, Z.; Mak, C.M.; Niu, J.; Tse, K.-T. Investigation into sensitivities of factors in outdoor thermal comfort indices. Build. Environ. 2018, 128, 129-142. [CrossRef]

16. De Hirashima, S.Q.S.; De Assis, E.S.; Nikolopoulou, M. Daytime thermal comfort in urban spaces: A field study in Brazil. Build. Environ. 2016, 107, 245-253. [CrossRef]

17. Atkinson, B. Meso-Scale Atmospheric Circulations; Academic Press: London, UK, 1981.

18. Simpson, J. Sea Breeze and Local Winds; Cambridge University Press: Cambridge, UK, 1994.

19. Miller, S.T.K. Sea breeze: Structure, forecasting, and impacts. Rev. Geophys. 2003, 41, 1011. [CrossRef]

20. Gilliam, R.C.; Raman, S.; Niyogi, D.D.S. Observational and Numerical Study on the Influence of Large-Scale Flow Direction and Coastline Shape on Sea-Breeze Evolution. Bound. Layer Meteorol. 2004, 111, 275-300. [CrossRef]

21. Qian, T.; Epifanio, C.C.; Zhang, F. Topographic Effects on the Tropical Land and Sea Breeze. J. Atmos. Sci. 2012, 69, 130-149. [CrossRef]

22. He, B.J.; Ding, L.; Prasad, D. Outdoor thermal environment of an open space under sea breeze: A mobile experience in a coastal city of Sydney, Australia. Urban Clim. 2020, 31, 100567. [CrossRef]

23. Vemado, F.; Pereira Filho, A.J. Severe weather caused by heat island and sea breeze effects in the metropolitan area of São paulo, Brazil. Adv. Meteorol. 2016, 2016. [CrossRef]

24. Mavrakou, T.; Philippopoulos, K.; Deligiorgi, D. The impact of sea breeze under different synoptic patterns on air pollution within Athens basin. Sci. Total Environ. 2012, 433, 31-43. [CrossRef]

25. Papanastasiou, D.K.; Melas, D. Climatology and impact on air quality of sea breeze in an urban coastal environment. Int. J. Climatol. 2009, 29, 305-315. [CrossRef]

26. Shang, F.; Chen, D.; Guo, X.; Lang, J.; Zhou, Y.; Li, Y.; Fu, X. Impact of Sea Breeze Circulation on the Transport of Ship Emissions in Tangshan Port, China. Atmosphere (Basel) 2019, 10, 723. [CrossRef]

27. Creel, L. Ripple Effects: Population and Coastal Regions; Population Reference Bureau: Washington, DC, USA, 2003.

28. Zhao, L.; Oppenheimer, M.; Zhu, Q.; Baldwin, J.W.; Ebi, K.L.; Bou-Zeid, E.; Guan, K.; Liu, X. Interactions between urban heat islands and heat waves-Supplementary Information. Environ. Res. Lett. 2018, 13, 034003. [CrossRef]

29. Zander, K.K.; Botzen, W.J.W.; Oppermann, E.; Kjellstrom, T.; Garnett, S.T. Heat stress causes substantial labour productivity loss in Australia. Nat. Clim. Chang. 2015, 5, 647-651. [CrossRef]

30. Umezaki, A.S.; Ribeiro, F.N.D.; De Oliveira, A.P.; Soares, J.; De Miranda, R.M. Numerical characterization of spatial and temporal evolution of summer urban heat island intensity in São Paulo, Brazil. Urban Clim. 2020, 32, 100615. [CrossRef]

31. Shen, L.; Sun, J.; Yuan, R. Idealized large-eddy simulation study of interaction between urban heat island and sea breeze circulations. Atmos. Res. 2018, 214, 338-347. [CrossRef] 
32. Ribeiro, F.N.D.; Oliveira, A.P.D.; Soares, J.; Miranda, R.M.D.; Barlage, M.; Chen, F. Effect of sea breeze propagation on the urban boundary layer of the metropolitan region of Sao Paulo, Brazil. Atmos. Res. 2018, 214, 174-188. [CrossRef]

33. Yamato, H.; Mikami, T.; Takahashi, H. Impact of sea breeze penetration over urban areas on midsummer temperature distributions in the Tokyo Metropolitan area. Int. J. Climatol. 2017. [CrossRef]

34. Freitas, E.D.; Rozoff, C.M.; Cotton, W.R.; Dias, P.L.S. Interactions of an urban heat island and sea-breeze circulations during winter over the metropolitan area of São Paulo, Brazil. Bound. Layer Meteorol. 2007, 122, 43-65. [CrossRef]

35. Hu, X.-M.; Xue, M. Influence of Synoptic Sea-Breeze Fronts on the Urban Heat Island Intensity in Dallas-Fort Worth, Texas. Mon. Weather Rev. 2016, 144, 1487-1507. [CrossRef]

36. Yamamoto, Y.; Ishikawa, H. Influence of urban spatial configuration and sea breeze on land surface temperature on summer clear-sky days. Urban Clim. 2020, 31, 100578. [CrossRef]

37. Sasaki, Y.; Matsuo, K.; Yokoyama, M.; Sasaki, M.; Tanaka, T.; Sadohara, S. Sea breeze effect mapping for mitigating summer urban warming: For making urban environmental climate map of Yokohama and its surrounding area. Urban Clim. 2018, 24, 529-550. [CrossRef]

38. Papanastasiou, D.K.; Melas, D.; Bartzanas, T.; Kittas, C. Temperature, comfort and pollution levels during heat waves and the role of sea breeze. Int. J. Biometeorol. 2010, 54, 307-317. [CrossRef] [PubMed]

39. Lopes, A.; Lopes, S.; Matzarakis, A.; Alcoforado, M.J. The influence of the summer sea breeze on thermal comfort in Funchal (Madeira). A contribution to tourism and urban planning. Meteorol. Z. 2011, 20, 553-564. [CrossRef]

40. Zhou, Y.; Guan, H.; Huang, C.; Fan, L.; Gharib, S.; Batelaan, O.; Simmons, C. Sea breeze cooling capacity and its influencing factors in a coastal city. Build. Environ. 2019, 166, 106408. [CrossRef]

41. IBGE. Estimated Population; IBGE Brazilian Institute of Geography and Statistics: Brasília, Brazil, 2019.

42. INMET Instituto Nacional de Meteorologia. Normais Climatológicas do Brasil 1981-2010. Available online:

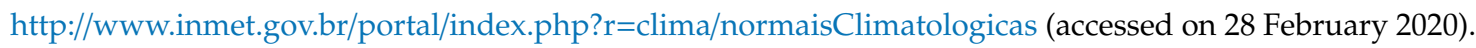

43. Anjos, M.; Lopes, A. Urban heat island and Park cool island intensities in the coastal city of Aracaju, North-eastern Brazil. Sustainability 2017, 9, 1379. [CrossRef]

44. Anjos, M.; Lopes, A.; Alves, E.D.L.; Lucena, A.J. de Rede climatológica de mesoescala aplicada ao estudo da Ilha de Calor Urbano: O caso de Aracaju-SE. Caminhos Geogr. 2017, 18, 203-216. [CrossRef]

45. Stewart, I.D.; Oke, T.R. Local Climate Zones for Urban Temperature Studies. Bull. Am. Meteorol. Soc. 2012, 93, 1879-1900. [CrossRef]

46. Anjos, M.; Targino, A.C.; Krecl, P.; Oukawa, G.Y.; Braga, R.F. Analysis of the urban heat island under different synoptic patterns using local climate zones. Build. Environ. 2020, 185, 107268. [CrossRef]

47. Kotharkar, R.; Bagade, A. Evaluating urban heat island in the critical local climate zones of an Indian city. Landsc. Urban Plan. 2018, 169, 92-104. [CrossRef]

48. Alexander, P.; Mills, G. Local Climate Classification and Dublin's Urban Heat Island. Atmosphere (Basel) 2014, 5, 755-774. [CrossRef]

49. Leconte, F.; Bouyer, J.; Claverie, R.; Pétrissans, M. Using Local Climate Zone scheme for UHI assessment: Evaluation of the method using mobile measurements. Build. Environ. 2015, 83, 39-49. [CrossRef]

50. Höppe, P. The physiological equivalent temperature-A universal index for the biometeorological assessment of the thermal environment. Int. J. Biometeorol. 1999, 43, 71-75. [CrossRef] [PubMed]

51. Matzarakis, A.; Rutz, F.; Mayer, H. Modelling radiation fluxes in simple and complex environments: Basics of the RayMan model. Int. J. Biometeorol. 2010, 54, 131-139. [CrossRef] [PubMed]

52. Matzarakis, A.; Rutz, F.; Mayer, H. Modelling radiation fluxes in simple and complex environments-Application of the RayMan model. Int. J. Biometeorol. 2007, 51, 323-334. [CrossRef]

53. Matzarakis, A.; De Rocco, M.; Najjar, G. Thermal bioclimate in Strasbourg-The 2003 heat wave. Theor. Appl. Climatol. 2009, 98, 209-220. [CrossRef]

54. Nouri, A.S.; Lopes, A.; Costa, J.P.; Matzarakis, A. Confronting potential future augmentations of the physiologically equivalent temperature through public space design: The case of Rossio, Lisbon. Sustain. Cities Soc. 2018, 37, 7-25. [CrossRef]

55. Oke, T.R.; Mills, G.; Christen, A.; Voogt, J.A. Urban Climates; Cambridge University Press: Cambridge, 2017; ISBN 9781139016476.

56. Gulyás, Á.; Unger, J.; Matzarakis, A. Assessment of the microclimatic and human comfort conditions in a complex urban environment: Modelling and measurements. Build. Environ. 2006, 41, 1713-1722. [CrossRef] 
57. Anjos, M. Application of Climatic Guidelines to Urban Planning in the Northeastern Coast of Brazil: Aracaju City (In Portuguese); University of Lisbon: Lisbon, Portugal, 2017.

58. Souza, S.H. Avaliação do Desempenho Térmico nos Microclimas das Praças: Piedade e Visconde de Cayrú, Salvador/BA (in Portuguese); Escola Politécnica da Universidade Federal da Bahia: Salvador, Brasil, 2010.

59. Lee, H.; Mayer, H.; Chen, L. Contribution of trees and grasslands to the mitigation of human heat stress in a residential district of Freiburg, Southwest Germany. Landsc. Urban Plan. 2016, 148, 37-50. [CrossRef]

60. Weather Underground. Available online: https://www.wunderground.com/weather/br/aracaju (accessed on 20 March 2014).

61. CPETEC/INPE Brazilian Center for Weather Forecasting and Climate Studies. Technical bulletin. Available online: http://tempo.cptec.inpe.br/boletimtecnico/pt (accessed on 1 September 2020).

62. Cavalcanti, I.F.A.; Justi, M.G.A.; Ferreira, N.J. Tempo e Clima no Brasil (in Portuguese); Oficina de Textos: São Paulo, Brasil, 2009.

63. Kousky, V.E.; Gan, M.A. Upper tropospheric cyclonic vortices in the tropical South Atlantic. Tellus 1981, 33, 538-551. [CrossRef]

64. Reboita, M.S.; Ambrizzi, T.; Silva, B.A.; Pinheiro, R.F.; Da Rocha, R.P. The South Atlantic Subtropical Anticyclone: Present and Future Climate. Front. Earth Sci. 2019, 7, 1-15. [CrossRef]

65. Houze, R.A. Mesoscale convective systems. Rev. Geophys. 2004, 42, RG4003. [CrossRef]

66. Lyra, M.J.A.; Da Silva, N.M.; Fedorova, N.; Levit, V. Mesoscale Convective Complexes and thunderstorm events in the Alagoas State, the Northeast Brazil. In 2015 International Symposium on Lightning Protection (XIII SIPDA); IEEE: Balneário Camboriú, Brazil, 2015; Volume 53, pp. 301-305.

67. Andrade, T.; Nery, J.; Freire, T.; Katzschner, D.F.L. Thermal Comfort Conditions for a Tropical City, Salvador-Brazil. In The 21st Conference on Passive and Low Energy Architecture; Technische Universiteit Eindhoven: Eindhoven, The Netherlands, 2004.

68. Abreu-Harbich, L.V.; Labaki, L.C.; Matzarakis, A. Thermal bioclimate as a factor in urban and architectural planning in tropical climates-The case of Campinas, Brazil. Urban Ecosyst. 2013, 16, 397-674. [CrossRef]

69. Ketterer, C.; Matzarakis, A. Mapping the Physiologically Equivalent Temperature in urban areas using artificial neural network. Landsc. Urban Plan. 2016, 150, 1-9. [CrossRef] 